\title{
Urban biodiversity: how the city can do its management?
}

\begin{abstract}
Concatenate urban biodiversity management and human population needs is one of the greatest society challenge, given the biological diversity loss and the urbanization process. In this sense, is necessary a discussion of how cities should develop public policies that have the biodiversity conservation as target. Here we showed some strategic plans (e.g. conservation units, environmental education) for urban biodiversity management with the involvement of different actors (e.g. universities, researchers, public governance) through three spheres: (i) politic, (ii) educative and (iii) ecological He we also pointed the mainly challenges for urban biodiversity conservation and strategic plans for this end. The case of the Sorocaba Municipality, São Paulo State, Brazil was discussed and the mainly direct actions for the local biodiversity were explored. Stands out the need of the 'Resilient City' concept adoption, knowledge about the biota (i.e. flora and fauna) and local environmental characteristics respect during the actions formulation.
\end{abstract}

Keywords: biodiversity, municipality, university, urban ecosystem
Volume 2 Issue 3 - 2018

\author{
Welber Senteio Smith, ${ }^{1,2}$ Fabio Leandro \\ da Silva, ${ }^{2}$ Sara Regina de Amorim, ${ }^{3}$ Marta \\ Severino Stefani ${ }^{2}$ \\ 'Laboratory of Structural and Functional Ecology, Paulista \\ Universiy, Brazil \\ ${ }^{2}$ Center of Water Resources and Environmental Studies \\ (CRHEA), University of São Paulo, Brazil \\ ${ }^{3}$ Municipal Secretariat of Environmental, Sorocaba Municipality, \\ Brazil
}

Correspondence: Welber Senteio Smith, Laboratory of Structural and functional Ecology, Paulista Universiy, Sorocaba, SP, Brazil, Tel +55 I599707 I994,

Email welber_smith@uol.com.br

Received: January 10, 2018 | Published: May II, 2018

\section{Introduction}

Nowadays, one of the greatest society challenges is concatenate biodiversity urban management with human population needs. ${ }^{1}$ Half of world population lives today in urban centers and the perspective is that until 2030 that population will duplicate. ${ }^{2}$ The relation between biological diversity and human occurs today mainly for what happens in the cities. The landscape urbanization occasioned the natural environment fragmentation, given the completely alteration in its ecological process to provide space for urban areas. ${ }^{1,3}$ The ecosystems that are located at cities, in particular green spaces and water bodies, provide an essential group of ecosystem services (e.g. water supply, local climate regulation, flood regulation, air purification, groundwater recharge, recreation) to human population. ${ }^{4}$

During the Convention on Biological Diversity (CBD) in 2002, was established as goal the reduction of biodiversity loss by 2010 . Although, a recent evaluation that considered many indicators showed that goal was not reached and the biodiversity loss is the faster ever observed. That confirmation reveals that public policies, when adopted, were inadequate and the lack between the stress on biodiversity and answers for its mitigation are increasing. ${ }^{5}$ In this way, the CDB parties assumed as compromise 20 new targets by 2020 , with the intention of reduce biodiversity loss, what made the United Nations call this decade as "biodiversity decade". 6

As the world becomes urban, researches and cities managers recognize the importance of provide an urban habitat that favors the biodiversity, what could be the beginning of an urban movement to promote wild flora and fauna. Cities are the continuity of natural ecosystems and the mainly human ecosystem. The urban ecology visualization and ecosystem services promote the planning and the sustainable urban management. The goal of the present study was promote the discussion of how cities can develop public policies with the biodiversity conservation as target.

\section{The urbanization and biodiversity}

The anthropic actions have been imperative in relation to the natural environment, with the humans facing great challenges referring to the limited capacity of ecosystems sustain the actual level of consumption due to economic activities and population growth. Results of this accelerate growth are innumerous adverse impacts to the natural environment and, consequently, human population. Among them, stand out: biodiversity loss; (ii) fauna and flora species extinction; (iii) rivers silting and (iv) climate changes. ${ }^{7}$ The urbanization is occurring at a scale and speed that ecosystems and biodiversity are failing to endure, which can difficult their resilience and resistance. By 2030, cities will expand something around 1.2 million square kilometers, resulting in a tripling in size terms. ${ }^{8}$

Even in scenarios of considerably lower urbanization rates, the urban areas across the globe are already facing serious challenges, including (i) natural resources shortages (including water) and environmental degradation, (ii) climate change, as manifested by sea level increases, higher temperatures, rainfall variation, floods, droughts, storms and heat waves with more intensity and frequency. This scenario is directly associated with biological diversity loss.

It is generally assumed that cities and biodiversity are incompatible, but the fact is that many cities have great species richness. ${ }^{9}$ Furthermore, while intact, the natural ecosystems harbor the richest biodiversity and are increasingly rare, natural landscape fragments (e.g. primitive forest fragments), agricultural traditional landscapes, restored landscapes and industrial landscapes (e.g. industrial parks, city centers), in addition to urban rivers and streams, are becoming refuges more common, becoming biodiversity refuges in cities. 


\section{Strategies for urban biodiversity management}

Front of the findings, how should biodiversity protection and conservation be carried out in the cities? How to make it? What is the solution for the problems? The conciliation of different actions that involve the public power, researchers, universities, environmental agencies, public ministry, NOGs and educational institutions seems to be the most efficiently way. ${ }^{10}$ The different actors integration makes the management more effective. In addition, conservation actions, inspections and environmental education look like the consensual way between scientific community and public managers to turn this process effective. Realism is in the awareness that the urban environment cannot be recreated from the zero, but it can be reinvent by fragments identification, actions implementation and green structures conservation that already exist and offer support to ecological and natural process. Down below are the main initiatives that urban public managers need to develop in order to achieve the efficiency of biodiversity management (Table 1).

Table I Mainly challenges for urban biodiversity conservation

\begin{tabular}{|c|c|}
\hline Elements & Description \\
\hline Politic willing & $\begin{array}{l}\text { The mayor, secretaries and politicians must to have the willing to invest in the biodiversity, providing } \\
\text { resources and base for thematic politics formulation }\end{array}$ \\
\hline Environmental Secretariat & Human resources qualified to safeguard the biodiversity and allow the city development \\
\hline Normative dispositive & $\begin{array}{l}\text { Municipal laws and decrees that established protection and conservation actions in all territory, including } \\
\text { rural areas }\end{array}$ \\
\hline Effective inspections & $\begin{array}{l}\text { In addition to partnerships with the environmental police, the municipality must to do the implementation } \\
\text { of a inspection policy through fiscal and environmental patrol }\end{array}$ \\
\hline Civil sector involvement & $\begin{array}{l}\text { The organized society can be involved in biodiversity actions, elements of conservation and biodiversity } \\
\text { protection must to be considered during the projects formulation and discussions }\end{array}$ \\
\hline Environmental Education & $\begin{array}{l}\text { It promotes a cultural change in a long time, what can be in favor to biodiversity conservation and } \\
\text { environmental sustainability }\end{array}$ \\
\hline Population awareness & $\begin{array}{l}\text { People should know about the city biodiversity and its importance to the society, including their role in } \\
\text { the conservation and protection process }\end{array}$ \\
\hline Strategic action & $\begin{array}{l}\text { Plans related with the municipality territory must to be influenced by biodiversity during their formulation, } \\
\text { what represent gains to conservation }\end{array}$ \\
\hline
\end{tabular}

The existence of a Municipal Secretariat of Environmental has as goal subsidizing and directing environmental actions. The creation of this secretariat and the growing research carried out in Sorocaba led to the beginning of a process that prompted discussions, reflections and implementation of local biodiversity protection policies. What also contributing to this process is the presence of the largest forest fragments concentration in the São Paulo State besides the presence of representative conservation units. The interface with universities ${ }^{10}$ aims professor's effective participation, researchers and agents from environmental agencies responsible for biodiversity survey in several municipality areas. Knowledge about wild flora and fauna is the starting point for management plans formulation and conservation of municipality water bodies and green areas, as well as it is an important tool for environmental monitoring and environmental education. In addition, biodiversity research and monitoring are vital information sources for ensure the biodiversity protection, and thus the evaluation of the municipality biodiversity state, a great challenge for Sorocaba. There is necessary more information available about the habitats, ecosystems, conservation status situation, among others, to ensure the biological preservation balance. The information was obtained from studies carried out by researchers, including scientific initiation, dissertations and theses works, besides books and published articles. Considering the Municipal Environmental Secretariat to establish legal instruments, guidelines and procedures standards for the management of Sorocaba biodiversity, also the need to establish local level activities that reflect the Convention on Biological Diversity targets. The biodiversity book elaborated in Sorocaba allowed the interaction between public authorities, universities and research, what constitute a strategy that consolidates the theme in the municipality (Table 2).

In this context, the implementations of environmental public policies are under the responsibility of actors and institutions group. Among these, stands out that the role of the local government, which in the brazilian case is represented by municipality, figure that is emphasized and has autonomy for the socio-environmental projects implementation that aimed promote the population well-being. The local governance, for this end, has a series of instruments for an environmental police consolidation in a sustained and efficient way. The requirement that local governments should care about the environment is no longer so recent. In the European Union, since 1986, the Conference of Local and Regional Authorities has demanded of the municipalities the creation of an environmental departments with qualified human resources, in line with the tendency for environmental issues to be worked through increasingly adapted decisions and actions to local realities.

Summary, today the municipalities in Brazil have several possibilities for instruments to protect their environment and biodiversity. In the item bellow, we present the Sorocaba experience, a municipality with a large population in São Paulo State, which has 
been evolving in its environmental public policies and, consequently, shows significant efforts to protect biodiversity.

Table 2 Strategic plans for biodiversity conservation

\begin{tabular}{|c|c|}
\hline Programs & Goals \\
\hline Environmental Education & Promote environmental awareness of the population \\
\hline $\begin{array}{l}\text { Conservation and protection of rivers, streams } \\
\text { and wetlands }\end{array}$ & $\begin{array}{l}\text { Adequate ecological management of aquatic systems, their quality recuperation and } \\
\text { maintenance of native biota }\end{array}$ \\
\hline Afforestation Plan & $\begin{array}{l}\text { Recovery of fragments with high ecological value, as well as maintenance of existing } \\
\text { native vegetation connectivity }\end{array}$ \\
\hline Creation of spaces for reflection & $\begin{array}{l}\text { Provide the opportunity to people have the relationship 'human-environment' at urban } \\
\text { area }\end{array}$ \\
\hline $\begin{array}{l}\text { Universities and environmental agencies } \\
\text { interlocution for research and biodiversity }\end{array}$ & $\begin{array}{l}\text { Development of works and tools that can meet local particularities and verify the } \\
\text { implemented actions effectiveness }\end{array}$ \\
\hline $\begin{array}{l}\text { monitoring } \\
\text { Creation of Municipality Conservation Unites }\end{array}$ & $\begin{array}{l}\text { Prevent the advancement of urban areas over remaining vegetation fragments and } \\
\text { safeguard the existing biodiversity }\end{array}$ \\
\hline $\begin{array}{l}\text { Recuperation of legal protect areas (e.g. } \\
\text { permanent protection areas) }\end{array}$ & $\begin{array}{l}\text { Accordance with existing legislation and public policies, as well as the potential increase } \\
\text { in areas for biodiversity conservation }\end{array}$ \\
\hline $\begin{array}{l}\text { Urban Afforestation Plan (e.g. gardens, } \\
\text { backyards) }\end{array}$ & $\begin{array}{l}\text { It extends the urban landscape permeability to biodiversity by providing propagules for } \\
\text { ecological restoration, food and shelter, what favor the gene flow between fragments of } \\
\text { high ecological value }\end{array}$ \\
\hline Environmental Zoning & $\begin{array}{l}\text { Zoning policy for landscape cover aligned with environmental macro-zoning, restricting } \\
\text { in this way the conversion and occupation of fragile areas (floodplains, endemic species } \\
\text { habitat) and allowing a territorial planning that respect the local peculiarities }\end{array}$ \\
\hline
\end{tabular}

\section{How to perform?}

Public managers should act under three spheres: political, educational and ecological. The Figure 1 shows the steps to be carried out in partnership with universities, environmental agencies, articulating different actors that work with the biodiversity agenda.

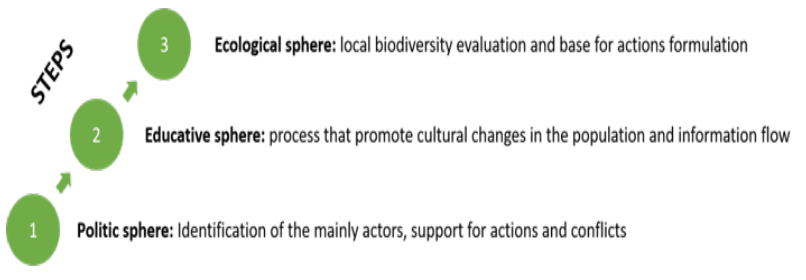

Figure I Representation of the steps to be performed by the project.

\section{Politic sphere}

The political sphere is the most complex because of it involves several interest conflicts and decisions that alter the action dynamic in the short, medium and long term. For this reason, the work in this area must to be initiated previously to verify the viability of programs and projects, and obtain support for their implementation. The main city political actors (e.g. Public Sector, Private Sector and Community) should be identified, with the purpose of obtaining support and developing the project understanding. This stage will reduce conflicts between the program proposal and local reality. Likewise, it will clarify the necessary priority actions and the conviction that this agenda is positive compared to other agendas related to health and education.

The creation of scenarios also can auxiliary the decision makers to verify the possible consequences of their policies application ${ }^{11}$ on biodiversity. The public managers can choose policies that promote the conservation and involve the landowners and provide base for decisions that allow a correct management ${ }^{12,13}$ and base to face the environmental problematic related with the social aspects. ${ }^{14}$

\section{Educational sphere}

In the educational sphere, we have the processes that involve enlightenment and changes in population habits. With the community, the environmental education work will allow the information exchange similar to the observed between the public and private sectors. Through workshops, lectures, visits and actions, the public power will publicize the project as well as indicate to the population that its participation is fundamental for success, in addition to its relationship with the theme. In another sense, various dissemination forms on biodiversity conservation and their importance in the municipality will be proposed. In the following Table 3 are the activities proposed to the work in this area.

\section{Ecological sphere}

This stage involves the information obtaining about the municipal biodiversity, using for this purpose studies already carried out by local universities or by encouraging new research. Inventorying the existing information is crucial. With the collected information, considering that the objective is also evaluate the proposed ecological actions and evaluate the current municipality situation, is possible to be work with the adaption the Biodiversity Index of Cities based in Singapore. ${ }^{15}$ The index, which incorporates 23 indicators, is based on three components: autochthonous biodiversity in urban system; ecosystem services provided by urban biodiversity and urban biodiversity governance and management. It is necessary to consider the community, since the anthropic alterations alter their composition due to species extinction and habitat destruction. ${ }^{16}$ The municipal administration must address these challenges and develop methods applicable to local scale and urban system, promoting elements that favor the natural process maintenance..$^{17,18}$ 
Table 3 Educative strategies for biodiversity conservation and knowledge diffusion

\begin{tabular}{ll}
\hline Action & Target \\
\hline $\begin{array}{l}\text { Training of teachers, undergraduate } \\
\text { students and technicians }\end{array}$ & Prepare the human resources for the biodiversity tasks execution and allow the information flow \\
Thematic exhibitions & $\begin{array}{l}\text { Work with the local biodiversity contents and creation of experiences with the public in alternative } \\
\text { spaces around the urban zone } \\
\text { Show to the population relevant information about the local biodiversity, identify places of relevant } \\
\text { interest and species occurrence, as well as educate the public about its importance for biological } \\
\text { diversity maintenance }\end{array}$ \\
Educational materials & $\begin{array}{l}\text { Enable environmental education by educators in the municipality through a didactic language and } \\
\text { dissemination of information on local biodiversity }\end{array}$ \\
Detail and provide a deep understanding of the issues related to local biodiversity, actions \\
necessary for its protection and the mainly objectives
\end{tabular}

The collected information during this stage will serve to define areas where biodiversity projects will be implemented. In addition, it includes guidelines for the implementation of interventions involving physical changes in the environment (i.e. habitat), such as scrubbing, planting, containment, demarcation and refuges signalization, educational campaigns among others. This stage is of vital importance to encourage new refuge areas, to create new conservation units, and to implement ecological restoration techniques and identify/apply good practices for the protection and biodiversity conservation. A series of municipal regulations that encourage the maintenance and creation of new protected areas, as well as public policies for biodiversity conservation can also be developed. In order to reach a higher efficiency level, this stage should integrate and commit the citizen, public power, institutions, the third sector and private initiative. The articulation of these actors could be possible through the creation of an interdependent committee, with the actions and objectives definition as purpose, establishing forums and ensuring compliance with current legislation. In another sense, based on environmental diagnosis data, public and private sector actors will be alerted to the proposed short, medium and long-term changes in the desired interventions.

\section{Case presentation}

The Sorocaba Municipality (São Paulo State, Brazil) has an area of $449.12 \mathrm{~km}^{2}$ and a population of 586,625 inhabitants, which $98 \%$ are living in the urban area. In this municipality, $81.5 \%$ of total area is urban and $18.5 \%$ is rural, revealing a high population density $\left(1,356.98\right.$ inhabitants $\left./ \mathrm{km}^{2}\right){ }^{19}$ Sorocaba is an old municipality and had undergone several economic cycles, which deeply influenced the socioeconomic and natural environment. Currently, only $16.9 \%{ }^{20}$ of the original Sorocaba Municipality vegetation still remain little altered, mainly concentrated in the rural landscape permanent preservation areas, given that Sorocaba presents a dense and perennial mesh water resources.

Facing this scenario, Sorocaba has been developing biodiversity conservation actions since 1970, through the creation of specially protected areas (e.g. Biquinha, ÁguaVermelha and Chico Mendes Parks), as well as developing actions to protect native wildlife and threatened extinction through Quinzinho de Barros Municipal Zoo. In the 1990s, Sorocaba River decontamination and degraded areas recovery began, through intercropped nurseries with production capacity of more than 200,000 native seedlings per year, of which more than 500,000 were planted with the plan planted in 2009 .

During 2009, Sorocaba Municipality, through the Municipal Secretariat of Environmental, showed by the "Programa Município Verde Azul" a significant evolution in its environmental performance, given the actions for restoration, conservation and biodiversity protection. This program aims to certify the best municipal practices in ten directives, and one of them is about biodiversity. It worth to be mentioned that in the last decade, there has been a significant advance in the creation of new parks and plazas to protect natural resources and biodiversity. However, not all areas are well established, consolidated or have with public use, but they already positively impact the landscape and are suitable for the realization of biological connectivity, hydric resources protection, biota protection, as well as public use for recreation and environmental education.

In addition to achieving institutional advances, public recognition and a good acceptance of the environmental agenda in municipal politics, the "Programa Município Verde Azul" has become a priority for governance. It has brought to Sorocaba the perspective of working in an integrated and intersectional way to deal with the environmental issues, among which biodiversity (e.g. integration of the actions of the Municipality with the Autonomous Water Service (SAAE) in the sewage topic; integration of municipal secretariats and SAAE to develop environmental education actions; development of environmental management instruments and public management indicators to disseminated information through environmental management reports).

Among the three actions were striking: The creation of the Park Municipal Natural and Biodiversity Corridors on 7th June of 2013, where 63 ha area of native vegetation has become the first municipality protected area, according to the criteria established by the National System of Units of Conservation (SNUC). The institution of the program 'Sorocaba: city of biodiversity' and the implementation of the 'Biodiversity Square' which is a concept space, fully sustainable, in which elements of the local flora and other structures were established, with the aim of providing shelter and food for local wildlife.

Recent studies (e.g. 21), point out the possibilities that the biodiversity corridors started in the park area could be integrated into a regional corridor integrating the Sorocaba River Conservation Zone and Pirajibu with the Environmental Protection Area - APA Itupararanga with the protected area Ipanema National Forest in Iperó 
Municipality. Stand out that the further development of these actions requires the investment in training of the municipality technical staff in sustainability, promotion of scientific technical meetings, strengthen environmental education in all areas and, most importantly, the stimulus of all sectors in public environmental policies in order to fulfill its objectives and to carry out actions.

\section{Municipality legislation from the biodiversity convention}

There are regulatory provisions on biodiversity in the municipality, but there is a need to implement activities that convey the three objectives of the Convention on Biological Diversity using mechanisms such as Biodiversity Action Strategies and Plans in accordance with the principles and guidelines for implementation of the National Biodiversity Policy. In 2012, the Municipal Environmental Policy was created (Law 10060/2012), in this device, the biodiversity protection is present in several passages, besides assigning the municipal government responsibility, together with other institutions, have to elaborate and disseminate the list of occurrence wild species in the segments of the natural and artificial ecosystems of the Municipality. Other important devices were Decree $n^{\circ} 19424 / 2011$ and Ordinary Law $n^{\circ} 10240 / 2012$, responsible for establishing the Municipal Natural Park Biodiversity Corridors and its advisory council, respectively. Stand out the Decrees 21618/2015 and 20012/2015, which instituted the Parque Natural Municipal Brigadeiro Tobias and the Estação Ecológica, do Pirajibu, and the Laws $\mathrm{n}^{\circ} 11234 / 2015$ and 11471/2016, which established the ecological stations Dr. Mario Covas e Bráulio Guedes da Silva. Worth to be mentioned the establishment of the Urban Tree Plan by Law 10521/2013, the Municipal System of Protected Areas and Public Space for Public Use by Law ${ }^{\circ} 11073 / 2015$, in agreement with the National System of Conservation Units and the Municipal Policy on Climate Changes (Law n ${ }^{\circ} 11447 / 2016$ ), mechanisms that have biodiversity places as one of the main aspects to be considered. Finally, the Municipal Environmental Education Policy (Law 7,854 / 2006) stands out, a device that allows people to raise awareness about issues related to biodiversity and the natural environment.

\section{Historical knowledge of the biodiversity of the municipality}

The Municipal Department of the Environment made numerous partnerships with universities to inventory biodiversity, culminating in a decree listing the species of the municipality, a book addressing its biodiversity, as well as research incentives with the theme. ${ }^{21}$

\section{Environmental education}

Some developed actions worth to be mentioned, among them stand out: (i) tour of the Sorocaba River - aim to sensitize the population regarding the preservation of the city's source through formal, educational and cognitive resources; (ii) tour "Sorocaba Citizens Trees" - a route composed of trees that have immunity to cutting according to law; (iii) dates alluding to the environment - day of the Sorocaba river; (iv) indicative plates and totems of fauna and flora that occur in the Sorocaba River - aim to sensitize the population and provides information about its conservation. In addition, numerous activities were implemented in the municipal parks, presenting the citizen with its biodiversity.

\section{Reforestation projects}

Through partnerships between municipal governance and universities, a work that had as focus in the diagnostic of the Sorocaba Municipality vegetation was concluded. Based on the work carried out, it is estimated that the Sorocaba tree vegetation present in the public roads is estimated in 110,338 trees. In this sense, the Urban Reforestation Plan has as goal expand the afforestation of the city through a technical, planned and participative process prioritizing the use of native species. The goal is the planting of 500,000 trees by 2012, thus establishing a crown projection area of $30 \mathrm{~m}^{2}$ per inhabitants. By 2019 , the target is $1,248,570$ seedlings, thus increasing the urban green area in $20 \%$. Besides that, during 2011 the reforestation project called 'Mega Plantio Escolar' was carried out, where the population was mobilized to recover the green areas near the educational institutions, in addition to Mega Planting, an action of the public power that had the goal of planting 500 thousand seedlings until 2012, of which 282,272 seedlings were planted.

\section{Biodiversity refuges}

The "Biodiversity Refuges" are strategic areas for management with low cost techniques that can be used for environmental education. Twenty-nine areas were chosen according to three criteria (presence of water bodies, remnant vegetation and native fauna and flora occurrence). The chosen areas were forest remnants, parks, green areas, squares and stretches of the banks of water bodies. The following steps were taken in the selection of sites: sensitization with the maintenance and cleaning teams, population awareness, and signage with educational boards, keeping grasses at sites with fauna incidence and planting of native species..$^{22}$

\section{Discussion}

The conciliation of different actions is the key for promote biodiversity conservation in urban areas, given the gain of effectiveness in the management and the community participation. A department responsible for the environmental sector is able to subsidizing and directs the strategic actions and normative dispositive application, which can have their formulation based by researchers. A great performance can be assured when the work is developed under the three essential spheres (i.e. politic, educative and ecological), factor that provide a solid base for the biodiversity management and public policies formulation. The adopted actions in Sorocaba Municipality are of the vital importance for urban biodiversity maintenance, although it is fundamental the involvement of all municipality sectors, including the public and private ones, what allow the success and the adequate biodiversity management. Here we showed that is possible to formulate actions for biological diversity protection and conservation in urban zones, through measures that have focus on the actual municipality situation and have influence on strategic planning and development process.

It stands out there is a need of the landscape cover zoning that is aligned with the environmental macro-zoning (e.g. eco-regional scale), what effectively prevents the occupation of important areas from the environmental perspective (e.g. wetlands, forest fragments with high ecological value) and provide a better territorial planning with environmental characteristics respect as premise. In this way, is possible to work with 'Smart Cities' concept, given the adverse impacts anticipation and necessary interventions realization (e.g. protect legally risk areas, highway alteration). 


\section{Conclusion}

Knowledge about wild flora and fauna is the initial point for the conservation plans elaboration that has focus on urban biodiversity, as well as being an important tool for environmental monitoring and provide base for the environmental management and education actions. The three spheres (i.e. politic, educative and ecological) consideration allows a better performance for the biodiversity conservation and the development of the vital strategies for that goal, mainly that ones that have the society involvement. The key steps for the urban biodiversity conservation should include environmental education, afforestation plans, partnerships between academia and the public sector, educative actions and special protection areas creation. Also is important to include the need of the landscape cover planning that respect local environmental characteristics, such as ecological corridors, natural habitat loss reduction and preventing the inadequate risk areas occupancy, anticipating in this way the adverse impacts and the application of the 'Resilient City' concept. In addition, biodiversity research and monitoring are vital sources of information to ensure the biodiversity protection, situation that is possible to realize in the Sorocaba Municipality case. There is necessary more information available about the status of species habitats, ecosystems functions, conservation status and others to ensure the biological balance preservation. The novelty here was show effective actions that the municipality can work with to safeguard its urban biodiversity, situation that can be easily performed with partnerships (academia, public sector, private sector and population) and the consideration of studies about the local biota, always fallowing the three spheres here discussed.

\section{Acknowledgements}

None.

\section{Conflict of interest}

The authors declared that there no conflicts of interest.

\section{References}

1. Cabral M, Pereira HM, Cruz CS, et al. O Índice de Biodiversidade nas Cidades como ferramenta para gestão: o caso da cidade de Lisboa. Ecologia. 2012;6:63-72.

2. United Nations Population Fund, State of World Population. Unleashing the Potential of Urban Growth. 2007.

3. McKinney ML. Urbanization, Biodiversity and Conservation: The impact of urbanization on native species are poorly studied, but educating a highly urbanized human population about these impacts can greatly improve species conservation in all ecosystems. BioScience. 2002;52(10):883-890.

4. Pereira HM, Domingos T, Vicente L, et al. Ecossistemas e Bem-Estar Humano: Avaliação para Portugal do Millennium Ecosystempartida das diferentes cidades. 1st ed. Escolar Editora, Lisboa, Portugal; 2009. p. 734.

5. Butchart SH, Walpole M, Collen B, et al. Global Biodiversity: Indicators of Recent Declines. Science. 2010;328(5982):1164-1168.
6. Convention on Biological Diversity. Decision X/2 -The Strategic Plan for Biodiversity 2011-2020 and the Aichi Targets. Nagoya, Japan; 2010.

7. Young OR, King LA, Schroeder H. Institutions and Environmental Challenges: Principal Findings, Applications, and Research Frontiers. 1st Ed. MA: MIT, Press, Cambridge, England; 2008.

8. ICLEI. Congress Report. 3rd Global Forum on Urban Resilience and Adaptation Congress Report Bonn. Local Governments for Sustainability. Resilient Cities. Germany; 2012.

9. Secretariat of the Convention on Biological Diversity. Cities and Biodiversity Outlook. Montreal; 2012. p. 68.

10. Castellari RR, Smith WS. Integration between the public authorities and universities in popularization of knowledge concerning biodiversity. Revbea. 2015;10(4):24-31.

11. Schulz C, Ioris AAR, Martin-Ortega J, et al. Prospects for Payments for Ecosystem Services in the Brazilian Pantanal: A Scenario Analysis. The Journal of Environment \& Development. 2015;24(1):26-53.

12. Van Der Horst D. Adoption of payments for ecosystem services: An application of the Hägerstrand model. Applied Geography. 2011;31(2):668676

13. Omernik JM, Griffith GE. Ecoregions of the Conterminous United States: Evolution of a Hierarchical Spatial Framework. Environmental Management. 2014;54(6):1249-1266.

14. Silva MP, Picharillo C, Silva GC, et al. Análise da influência dos aspectos sociais na percepção ambiental da população residente na microbacia do Córrego do Mineirinho, município de São Carlos-SP. Revista Eixo. 2015;4(2):91-99.

15. Secretariat of the Convention on Biological Diversity. National Biodiversity Strategies and Action Plans. Series B-8: Biodiversity Planning for States, Provinces, Cities and Other Local Authorities: How to Develop a SubNational Biodiversity Strategy and Action Plan; 2011.

16. Kaiser-Bunbury CN, Muff S, Memmott J, et al. The robustness of pollination networks to the loss of species and interactions: a quantitative approach incorporating pollinator behaviour. Ecology Letters. 2010;13(4):442-452.

17. Hostetler M, Allen W, Meurk C. Conserving urban biodiversity? Creating green infrastructure is only the first step. Landscape and Urban Planning. 2011;100(4):369-371.

18. Larondelle N, Haase D. Urban ecosystem services assessment along a rural-urban gradient: A cross-analysis of European cities. Ecological Indicators. 2013;29:179-190.

19. IBGE. Cidades. Sorocaba; 2013.

20. Bortoleto LA, Figueira CJM, Dunning JB, et al. Suitability index for restoration in landscapes: An alternative proposal for restoration projects. Ecological Indicators. 2016;60:724-735.

21. Smith WS, Mota Jr. VD, Carvalho JL. Biodiversidade do Município de Sorocaba. Prefeitura Municipal de Sorocaba, Secretaria de Meio Ambiente, Sorocaba, Brazil; 2014. p. 272

22. Smith WS, Castellari RR, Sanches MA. Como fomentar "Refúgios" de biodiversidade em cidades, utilizando estratégias de baixo custo. Revista Hipótese. 2016;2(2):131-144. 